\title{
Revisiting justice in the first four Beatitudes in Matthew (5:3-6) and the story of the Canaanite woman (Mt 15:21-28): A postcolonial reading
}

\author{
Lazare S Rukundwa \& Andries G Van Aarde ${ }^{1}$ \\ Department of New Testament Studies \\ University of Pretoria
}

\begin{abstract}
Reading the Gospel of Matthew from the perspective of postcolonial theory means taking the context of the Gospel seriously. The political and religious circumstances of Palestine under Roman colonization influenced Matthean redaction. From a this perspective, it can be argued that Matthew presents Jesus as a revolutionary leader whose divine mission was to challenge and overthrow the Roman empire and its local collaborators on behalf of the poor, the powerless, the afflicted, the hungry and the outcasts. His mission was to replace existing power structures with the universal, just and powerful kingdom of heaven on earth. The article argues that the story of the Canaanite woman (Mt 15:2128) falls into this reality. She negotiates justice and righteousness on behalf of her demon-possessed daughter. Seen from the perspective of Jesus' Beatitudes in Matthew (5:3-6), her encounter with Jesus helps him discover the wider scope of his healing mission, beyond geopolitical and cultural boundaries.
\end{abstract}

\section{INTRODUCTION}

The first four Beatitudes set out the religious, political, social and economic reforms that Jesus introduces in his revolutionary speech on the mountain (Mt $5: 1-2)$. He announces the kingdom to "the poor in spirit" (Mt 5:3), ${ }^{2}$ inheritance of the land to the meek (Mt 5:5), consolation to the mourners (Mt 5:4), and

\footnotetext{
${ }^{1}$ Lazare S Rukundwa is the Executive Secretary of Eben-Ezer Ministry International in the Democratic Republic of Congo. This article is based on his PhD degree in New Testament Studies at the Faculty of Theology, University of Pretoria, entitled "Justice and righteousness in the Matthean theology and its relevance to the Banyamulenge community: A postcolonial reading", completed under the supervision of Prof Dr A G Van Aarde.

${ }^{2}$ The New International Version (NIV) Bible was used for biblical references in this article.
} 


\section{Revisiting justice in the first four beatitudes in Matthew}

satisfaction to those who are hungry and thirsty for righteousness (Mt 5:6). The proclamation of the kingdom of heaven - a God-with-us kingdom - sums up the will of God on earth as it is in heaven (Mt 6:10). The kingdom of heaven is a representation of a wholeness of life, shalom, a situation of wellbeing which was absent under Roman colonial rule and its religious collaborators in Palestine.

Using postcolonial theory, this article presents the argument that these macarisms are Matthean responses to the particular social, religious and political circumstances of his time. The call to justice and righteousness was renewed under the leadership of Jesus Christ, who had come to do the will of God. It is on the basis of this call that the Canaanite woman stands firm and claims the wholeness for her demon-possessed daughter that she has been denied socially, politically and religiously. According to Matthew, as Jesus gradually discovers the mission of his Father, he is also informed that the will of God entails salvation for all humanity. The kingdom of God which is announced was to replace the Roman empire and its local agencies which oppressed God's people by inflicting poverty on them, leaving them afflicted, in poor health and harassed.

Postcolonial theory (see Bhabha 1994:171; Dube 1996; Sugirtharajah 1999:3-5; 2001; Segovia 2000; Young 2001:1-11; 57-69) was inspired by the anti-slavery and anti-colonial liberation struggles in tricontinental countries ${ }^{3}$. This theory can be defined as a dialectical discourse that marks the broad historical facts of decolonization. A postcolonial critique allows people emerging from socio-political and economic domination to achieve their own sovereignty. It negotiates space for the marginalized to speak and to belong. In this process, a hybrid society (see Bhabha 1994:112-116; Young 1995:128) emerges, with a mixture of races and tribes, colonizer/colonized, rich/poor, high/low classes, masculinity/femininity, and all members of this society become equal in terms of their access to justice and righteousness.

It is argued that through his revolutionary speech on the mountain, the Matthean Jesus becomes the spokesperson of and for the oppressed. He exposes their injustice and reclaims their socio-political and religious reintegration, not in Roman colonial structures, but more specifically in the pronounced kingdom of God. In this context of the Gospel of Matthew, gives rise to a community of equality where all people, regardless of their origins, are treated with dignity and care.

\footnotetext{
${ }^{3}$ The term "tricontinental" is a replacement of the "third world" which has been widely used to differentiate developed and the undeveloped continents. For some postcolonial theorists the term "third world" itself is colonial, and thus inappropriate to be used, and tricontinental is preferred instead (see Young 2001:57-58; 2003:16-20).
} 


\section{THE FIRST FOUR BEATITUDES}

\subsection{Jesus and the crowds on the mountain (Mt 5:1-2)}

The attitude of Jesus as described in the introduction to the Beatitudes ${ }^{4}$ draws the reader's attention. In the interest of the crowds (ochloi) (Mt 5:1; 9:36), Jesus is confronted with some of the realities of his time. He meets people who are weary and burdened (Mt 11:28-30) who can bear no further injustice imposed on them by political repression, or by socio-economic and religious exploitation. When one reads the Sermon on the Mountain from the perspective of anti-colonial struggles, particularly in line with Amircal Cabral's (1980:81) view on "unity and struggle", Jesus' solidarity with peasants is highlighted. It is quite probable that after seeing the devastated condition of the crowds, which neither the Roman regime nor the religious leaders were responding to, Jesus was forced to act and to create a space for them to speak. Cabral argues that every struggle should be owned by people and that the reason for that struggle is the people's aspirations and desire for justice and progress.

It is therefore, not surprising to see that exegetes have made much use of the Moses typology in Matthew's gospel (e g, Sabourin 1982:325-327; Luz [1989]1990:224; Allison 1993:172-181; Garland 1993:51-52; Hagner 1993:86; Carter 2000:129-130). Israel trusted Moses' leadership to deliver them from Pharaoh's oppression and enslavement (Ex 1:1-2:10; 5:1-6:1-13). Moses consecrated his life to leading the Israelites who came to him to seek the will of God (Ex 18:15). The "crowds" to whom Matthew refers were under Roman occupation and oppression and longed for a Saviour who would bring deliverance (Mt 1:23) to the people of God. These "crowds" pressed Jesus to heal them (Mt 4:24-25; Mk 3:7-11) and to feed them (Mt 5:6; 14:13-21; 15:2939; Mk 8:1-10). Mourners longed for consolation and comfort (Mt 2:18; 5:4; $14: 10 ; 23: 35-37$ ), and the homeless (cf Mt 8:20) desired housing and family warmth.

Jesus' ascension on the mountain was an act that challenged imperial rule and manifested God's healing presence (cf Carter 2000:129-130). In this act, he implicitly reclaimed the land for its owners, explicitly proclaimed God's kingdom of justice and righteousness to the poor, and comforted mourners who suffered because of injustice.

The way in which the oros (mountain) concept is used here should not be taken for granted (see Donaldson 1985). Camping on the mountain (Mt $5: 1$ ) in the presence of the crowds (Mt 4:25; $5: 1 ; 9: 36$ ) can be read as a sign

\footnotetext{
${ }^{4}$ See Dupont (1969a, 1969b, 1973); Boice (1972); Van Tilborg (1986); Luz ([1989] 1990:209460); Sabourin (1982:335-353); Powell (1996:460-479).
} 


\section{Revisiting justice in the first four beatitudes in Matthew}

of defiance to the existing power structures that exploited and harassed the people, and unjustly occupied the land. Jesus had already engaged and defeated evil powers on the mountain (Mt 4:1-11). Later, he also healed the multitudes and fed great crowds (15:29-39) at a mountainside. A transfiguration ceremony took place on a mountain during a consultative meeting with heavenly emissaries (Mt 17:1-11). On the mount of Olives (Mt 24:3), he led his disciples in an eschatological teaching. He met his disciples at a mountain after overcoming death, which is the last measure of punishment imposed by a tyrannous government (Mt 28:16-18). In his postpaschal address, Jesus commanded his disciples to go and claim not only Palestine but the world back for God's rule (Mt 28:19-20).

Abraham, the father of faith, also strengthened his friendship with God at Moriah (Gn 22:1-19). At mount Horeb (Ex 3), Moses negotiated with God about the political future of Israelite refugees and slaves. He planned for their deliverance. Moses camped on a hill while Joshua fought against the Amelekites (Ex 17:8-15); Moses sojourned at Sinai in the company of the divine host, whereby Israel was given a new identity (Ex 19:1-17; 20:1-21). Elijah at the mountain Carmel (1 Ki 18:16-39) challenged Ahab's exploitative rule, which had fallen from God's standards of justice and righteousness.

In the twentieth century, in Martin Luther King's ([1968] 1992) prophetic speech "I have a dream", the image of the mountain is paramount. In his speech on the struggle against racism and social injustice inflicted upon the poor by the United States government, King ([1968] 1992:192-203) took fellow African-Americans and other members of his audience with him up to "the mountaintop", and he saw in his "dream" the promised land, where equality and mutual respect reigns. Therefore, territorial occupation by or on behalf of the oppressed is a revolutionary position which offers a better space for the Matthean Jesus to defend the dignity of the defenceless and be the voice of the voiceless. The Matthean Jesus places himself in a locality which implies his following in the footsteps of the God of Exodus, whose definition of justice and righteousness means taking side with the oppressed (cf Pixley \& Boff 1995:218).

Seen in this light, the Matthean Beatitudes expose and challenge (cf Carter 2000:131) the existing social, political and religious structures which impose suffering on people. At the same time, they also express God's transforming power, which can limit or eradicate the power of the Roman empire and all oppressive structures.

\footnotetext{
${ }^{5}$ This is a figurative concept in King's speech.
} 


\subsection{The poor and ownership of the kingdom of heaven (Mt 5:3)}

There are three Greek words that translate the word "poor" or "poverty" (Dupont 1969b:19-34), namely penichros, penes and ptochos. Penichros refers to the poor or the needy (Lk 12:2); penes refers to a poor person or day labourer, and ptochos means a beggar. The latter term is used by Matthew to refer to the poor (Mt 5:3; 11:5, 19:21; 26:11). Van Tilborg (1986:14-19) argues that the term beggar is used in Matthew for those who depend on nothing but God's provision.

Luz ([1989] 1990:231) concedes that ptochos is the strongest available Greek word for social poverty. The term ptochos is also used in the Septuagint and it emphasizes the social aspects that correspond to Jesus' meaning in the Beatitudes. Unlike Luke, who clearly states poverty in social circumstances (Lk 6:20), the Matthean addition "in spirit" can be ambiguous. Dupont (1969a:216-217) and Luz ([1989] 1990:232) prudently question the use of "ptochos to pneumatai", which shifts the meaning by moving from a social to a spiritual connotation: piety or voluntary poverty. Bligh (1975:43-44) and Hagner (1993:92) argue that Matthew is talking about voluntary poverty, while Sabourin (1982:342-343) thinks that the connotation carries a religious signification. Bligh's implication is that the term "poor in spirit" seems to refer to "something other than real, economic poverty".

Hare (1993:36-37) on the other hand, argues that the phrase "the poor in spirit" refers neither to those who are poor for religious reasons (voluntarily poor), nor to those who are deficient with respect to spirit, but to those "who manifest the attitude, appropriate to their condition", that is, humble dependence on God's grace. However, quoting A Pieris, Phan (1997:226) explains two kinds of poverty: "forced poverty" which is the fruit of injustice, and "voluntary poverty" which is "the seed of liberation". In other words, voluntary poverty can be embraced in solidarity with the poor in a protest against imposed poverty. Consequently, liberation can be seen as twofold: as "an interior emancipation from spiritual slavery", and as a "release from sociopolitical and economic enslavement".

The argument is that Jesus is talking to people whose poverty has been imposed on them by social, political and religious circumstances in which the victims have no control. Powell (1996:463-464) adds that the Hebrew word anawim is semantically equivalent to "poor in spirit" and that this emphasis on spiritual poverty "redefines them as people who may be on the verge of giving up". It can be convincingly argued that the Matthean audience is "poor in spirit" because they have no reason for hope in their current unjust state. 


\section{Revisiting justice in the first four beatitudes in Matthew}

However, Jesus' proclamation that the kingdom of God belongs to "the poor in spirit" implies the accomplishment of God's will as a holistic mission. Arguing from the perspective of the Mediterranean societal codes of honour and shame, Malina and Rohrbaugh (1992:48) comment that to be poor means to fall below the status into which one was born. ${ }^{6}$ The proclamation of the kingdom of heaven to the poor (Mt 5:3b) therefore means a complete reversal of circumstances and a complete restoration human dignity.

The essence of "belonging" is in itself a revolutionary concept for the poor and the marginalized. It implies something similar to a certitude of citizenship - and in a Roman colony not everyone had a right to citizenship. This is clear in the account of Paul and Silas' imprisonment at Philippi (Ac 16:35-40). It was mainly prominent people in politics and businesses who were given Roman citizenship. Kee (1997:200-201; cf Witherington 1998:499502) explains that "select ... indigenous leaders in the coloniae would be designated as Roman citizens" while other residents were called incolae (resident aliens). Citizens generally served as members of the civic councils and were chosen from the wealthy families in the community. They were appointed for life. However, an exception was made for slaves who were "manumitted by citizens", as well as military veterans and their sons.

Consequently, Palestine had many people who were stateless, and it is these people to whom the kingdom of God gives preference.

As part of his ministry to the needy, Jesus proclaimed a kingdom of justice and righteousness by healing the sick (for example, in Mt 4:23-25; 8:1$17 ; 9: 1-8,18-34 ; 12: 9-14 ; 17: 14-18)$ and welcoming tax collectors, prostitutes, Gentiles (Mt 21:31;15:21-28) and the rejected children (Mt 19:13-15; see Van Aarde 2001:135-154). He challenged the rich on behalf of the poor (Mt 19:24). He fed the hungry (Mt 8:5-13; 12:1-8; 14:13-21; 15:29-39) and defied the religious rulers on behalf of justice and righteousness (Mt 12:1-14; 23:15-39; 23).

Carter (2000:131) argues that the meaning of "poor" in Matthew's gospel should not be understood in either a figurative or a spiritualised way. They were the literally and physically destitute people in the Judean community. They were those who "lack adequate resources". They were exploited and oppressed by the wealthy and powerful. These "poor" people included aliens, widows, orphans, the physically handicapped and the powerless (Lev 19:10, 15; Dt 24:19-21; Job 29:12-16; Pr 14:31; Mt 21:14). Van Tilborg (1986:19) mentions that Jesus' proclamation of the basileia restored the "quality of a person" because it implies that God's power reigns

\footnotetext{
${ }^{6}$ Beyond this definition, there are also those who are born poor. According to Israelite tradition, all those born with infirmities were considered unclean and thus poor.
} 
against the power of dictatorship and leads to the liberty of subjects (see also Is $61: 1-2$, as quoted in Lk 4:18-19). Therefore, "the poor in spirit" is to be understood in the light of hopelessness and despondency in the lives of those who were oppressed by the existing power structures.

Dupont (1969b:105-123; cf Horsley 1993:165-172) also explains the essence of God's basileia as "good news" proclaimed to despondent people. God's basileia became a reality for and among these people because the basileia "belongs" to them. According to Sabourin (1982:341), this promise of the kingdom points to the whole "divine economy" of the messianic age, proclaimed and enacted by Jesus, who defended the weak. The good news to the poor, according to Dupont (1969b:104), is that "Dieu ... va prendre la défense de son peuple opprimé et lui accorder le salut". God invites all men to co-work with God in doing justice to the poor and in comforting the afflicted.

\subsection{Consolation of mourners (Mt 5:4)}

This Beatitude says that those who mourn will be comforted. According to Dupont (1969b:35-37; cf Sabourin 1982:344), there are two Greek words that explain the situation of these mourners and afflicted. Lupe is the general word for pain, sorrow and affliction, whereas the word penthos refers to affliction that is more acute and is often externalised by tears and lamentations. Sometimes the word penthos is associated with the word klaio, to weep. ${ }^{7}$ In consequence, it is worth noting that Luke, narrating the same speech of Jesus that the Matthean Beatitude pertains to, refers to those who weep (Lk 6:21).

Seen cross-culturally, mourning rituals are diverse. Yet what is important, regardless of culture, is that the bereaved need to be comforted (see Is 61:2-3; Mk 16:10; Lk 8:52; 23:27; Jn 11:1-44; Ac 8:2; 9:36; Rv 5:5). Matthew records mothers in Bethlehem mourning their innocent children (boys) who had been killed in a brutal and ruthless massacre by Herod (Mt 2:16). This reminds the reader of the Egyptian Pharaoh's evil plan of ethnic cleansing, which left Israelite mothers uncomforted (Ex 1:15-2:1-10); and of the Egyptian women (Ex 11), whose innocent firstborns are killed by an angel in punishment of Pharaoh's oppressive regime over the Israelites in Egypt.

According to Van Tilborg (1986:21), Matthew starts his Gospel by mentioning "violence, deceit, and royal arbitrariness". This narration should be seen against a background where the suffering of people was not a fiction, but a daily reality. In sorrow, fear and confusion, families fled their homes and country with little hope of returning to their country or region of birth (Mt 2:22); mothers could not be consoled (Mt 2:5-6; Mc 5:2) in a land where the tears

\footnotetext{
${ }^{7}$ Theological Dictionary of the New Testament 1968. S v "penthos".
} 


\section{Revisiting justice in the first four beatitudes in Matthew}

and lamentations of the innocents go unheard. People mourned and longed for justice and righteousness, because they had been denied justice and they lived under the pressure of debts, taxes and landlessness (Carter 2000:133). In short, people constantly lived under the shadow of death (Mt 4:16).

Jesus, a rescapé of the massacre mentioned at the beginning of the narrative (Mt 2:13) - one who, so to speak, grew up in a refugee camp (Mt 2:14-15) and in a displaced location (Mt 2:19-23) - turns into a "liberated liberator" (Wainwright 1998:60-66) and a "comforter" (Is 40:1; 49:13; 51:3; 61:2; Jr 31:13) in Matthew's story. Jesus and his family - who had experienced injustice and misery from Roman brute force - understood the language of these "mourners". Van Tilborg (1986:22) is convinced that Matthew presents Jesus as "someone who knows whereof he speaks". The Matthean audience were not strangers to mourning. They too fell victim to daily injustice and violence perpetrated by brutal colonial powers. Those who were not killed by the sword were killed by famine and disease due to a lack of health care.

The Roman regime used (excessive) force to discourage any attempt at opposition to its interests, ironically called the "peace of Rome" (pax Romana). The crucifixion of Jesus (Mt 28:32) was politically and religiously a relief to both the Romans and the religious leaders of Israel. As the "mourning of mothers" anticipated his death in Matthew, in Luke he comforted the "women of Jerusalem" when he faced this death (Lk 23:28). Matthew refers in the Beatitudes to the same kind of comfort. The implication is that, even in death, Jesus challenged the Roman and the religious leaders' failure to do justice and act righteously. His joyful and victorious resurrection therefore caused a scandal that shook these same rulers, but brought hope and strength to the community of his followers (cf Neh 8:10).

\subsection{The meek who inherit the land (Mt 5:5)}

The word praus refers to being meek, gentle or humble and Matthew uses it three times (Mt 5:5; 11:29 and 21:5). It can also refer to the powerless, the poor and the afflicted (Carter 2000:132-133; see Dupont 1969b:19-90). The meek (Mt 5:5) are those who were dispossessed of their land and dignity. They are those who were evicted from the land due to debts, insecurity and war. The land of their ancestors has been taken from them by the powerful, while they - the meek - watched helplessly. They are those who were dissatisfied with the current socio-economic, political and religious exploitation and discrimination. 
Land ${ }^{8}$ was an ancestral inheritance associated with the socioeconomic, political and religious identity of a people (cf Lk 2:1-7). Landless people were permanent strangers and wanderers, people with no identity, with no physical location to call their own (cf Ex 2:22; 1 Pt 1:1). In Israelite culture, land ownership (see Van Tilborg 1986:23-27; Freyne 1980:155-170; Oakman 1986:141-156) was inherited within a family, and ancestral land could only be sold to another member of the family or a countryman (Lv 25:25-28). This custom was in accordance with the principles of Jubilee, according to which the original owner would get it back (Lv 25:8-34). Although the land could be leased to a stranger in times of need, it could never be sold to this stranger (see Van Tilborg 1986:23-26). The reason is that the land remains the property of God (Lv 25:23). Van Tilborg (1986:24) quotes Philo as saying that "the whole country is called God's property, and it is against religion to have anything that is God's property registered under other masters". Against this background it was difficult, if not impossible, to make any sales contract for land. The story of Naboth and king Ahab is relevant here (1 Ki 21).

However, under Roman occupation, the laws regarding land were reformulated and implemented to serve the interests of the Romans and their local agents. According to Van Tilborg (1986:24), legal protection of the land was abolished or just ignored. Instead the land became "an object of trade". Moreover, circumstances of war led peasants to lose their land some were forced into exile, others were forced to sell their land in order to live (Mt 6:25-34) - or they lost it because they were unable to pay their taxes and/or debts. The parable of the tenants (Mt 21:33-41) explains this hardship and the desperate situation of peasants. This land reform led to the loss of the protection and ownership of the land as belonging to the clan or the family.

Van Tilborg (1986:25) notes that during the post-war period after $70 \mathrm{CE}$, the Roman emperor took and confiscated "vast tracts of land, declared them as his personal property and/or gave them on loan to veterans and collaborators". ${ }^{9}$ It is because of these "sins of oppression" (Carter 2001:70), domination and economic greed that the world needed a messianic saviour. These were the circumstances in which Matthew evoked the second Beatitude in which the powerless - those who cannot defend or speak for themselves, the subalterns (Guha 1982; Spivak 1988:197-221; Young

\footnotetext{
${ }^{8}$ According to Lohfink (1997:236-237), God's will is that peaceful and egalitarian possession of the land "is the highest salvation good, and thus faith and the economy are closely connected to each other."

${ }^{9}$ This is also argued in Mishnah, that because of "the [siqariqôn] - the laws dealing with purchase of the confiscated property - it is clear that Jewish countermeasures were necessary" (Van Tilborg 1986:25).
} 


\section{Revisiting justice in the first four beatitudes in Matthew}

2001:352); those whose land is taken from them - will be restored. Matthew did not submit to and did not concede this defeat; he still expected a "comeback" through a divine messianic plan that would make Israel whole once more.

God's reign on behalf of the destitute is ever present among his people. However, this presence is qualitatively different from that of the Roman emperor. The words in the Lord 's Prayer (Mt 6:9-15), "may your kingdom come", are yet another confirmation of the people's lack of confidence in Roman rule. For Matthew - apparently a Judean (cf Allison 1993:172-206; Luz [1993] 1995:30-41) - the memory of the theocratic reign described in Exodus was refreshed when he narrated God's presence, the presence of God who previously dwelt among the Israelites (Ex 33:12-20). It is as if the Jubilee was not just an imaginary festival, but really celebrated debts forgiven and slaves set free, while the land was restored to God as its owner and therefore to God's people, who had lost the land (Lv 25; Dt 15).

Oakman (1999:139) points out that Jesus' religion spoke to an "immediate need in the concrete terms". That is, God's kingdom of justice and righteousness had to resist a massive illegal accumulation of land through taxes and defaults on high-interest loan, which deprived peasants of access to the resources they needed to stay alive (see Carter 2000:133). The God of Israel had instructed his people to do justice so that they may live in the land (Dt 16:18-20). If there are those who desire to do justice and righteousness on behalf of those whose justice has been denied, the land and resources that are available will be enough for all. The presence of the kingdom of God is a consolation to the landless and the afflicted and a satisfaction to those who are hungry and thirsty in the community.

\subsection{Those who hunger and thirst for righteousness (Mt 5:6)}

Joy is not promised only to the mourners, but also to the hungry and thirsty who will be satisfied. According to Van Tilborg (1986:28), by remodelling the Beatitude which refers to those who hunger for a meal and thirst for water into a desire, Matthew explains how people longed for justice. Carter (2000:133) argues that the concern was with "unjust practices" in connection with land, access to resources, taxes and debts. People were dissatisfied with "the status quo of exploitive social relations".

Hunger and thirst should not, in this case, be taken as a metaphor, as the "poor in spirit" has been often understood. It speaks about the real life in Jesus' and in Matthew's times. According to the Theological Dictionary of the New Testament (1968), there are two Greek words that express the concept of hunger. The word peino means "to desire for something". It can refer to 
people who are "painfully deficient" of the basic needs of life and since they cannot help themselves, they turn to God. On the other hand, the Greek word limo means "to lack" and it denotes an acute lack of food as a result of the absence of means or supplies. In ancient Near East societies, such as Mesopotamia, Ugarit, Egypt and Israel (see Dupont 1969b:54-90; Weinfeld 1995), it was a social and political duty of rulers to ensure a subsistence level which would keep their subjects from starvation and would protect them from affliction. The story of the Egyptian pharaoh and the role that Joseph played in Egypt, according to Genesis 41, is a good example of this patronage. Hammurabi too (see Richardson 2000:33, 37) said that he was the Mesopotamian king who "protects the people of Malgium from catastrophes, who secures their habitations with plentiful supplies" of food and water. In the Old Testament the God of Israel is identified as this chief supplier of food and water (e g, Ex 15:22-27; 16:1-17:1-7; Ps 23).

Palestine, being a desert country where the sun was scorching and sand and wind storms were frequent, "thirst was man's constant companion" (Boice 1972:46-47). The Matthean community would have been acquainted with the life stories of people who had experienced severe famines caused by either droughts, poor harvests, earthquakes or insecurity and wars circumstances that had caused peasants to be unable to cultivate and harvest their fields. Life was expensive and the dislocated people in cities - people with no jobs and other means of living, refugees and internally displaced people (cf Segal 1991:28; see Stark 1991:189-205) - were the most affected. The report in the Acts of the Apostles (12:20) about the people of Tyre and Sidon who compromised their justice for food supply is an indication of how people struggled for survival. ${ }^{10}$

Ethics according to the Israelite tradition demanded sharing with the needy (e g, Dt 24:12-15, 17-22; Job 22:7; $\operatorname{Pr} 25: 21$; Is 32:6; 58:7-10; Ez 18:7). Matthew would know this old tradition (see Mt 6:2; 10:42; 14:13-21; 15:29-39; 25:35-46). On humanitarian grounds, even non-Israelites helped in emergency feeding programmes. Elijah was rescued by a Sidonian widow (1 Ki 17:7-15). Paul personally invested much to make a collection in Diaspora on behalf of the poor in Judea a success (e g, 2 Cor 8-9). Hence, according to Dupont (1969b:39), the audience that the Matthean Jesus addressed consisted of people with no means of survival. Not only were they hungry, but they also had no means to procure food and water to quench their hunger and thirst - these were the "pauvres, qui ne disposent pas du minimum vital."

From an African perspective, Ukpong's (1992:55-64) reading of the parable of the sheep and goats (Mt 25:31-46), a reading in search of an

\footnotetext{
${ }^{10}$ In extreme instances people roasted their children for food (Barbour 1988:222-223).
} 


\section{Revisiting justice in the first four beatitudes in Matthew}

"African christology" - is important. Ukpong argues that the hungry and thirsty could have been those people in Africa who do not have the basic necessities of life. These include millions of destitute people, wandering in the streets of African cities and their suburbs from Cape Town to Cairo via Zimbabwe and the Democratic Republic of Congo. Africa has millions of street children, refugees, internally displaced people and poor whose means of survival is begging. They are the kind of people with whom Jesus identified himself. In search of an "African women hermeneutics", Oduyoye (1998:362) argues that "African theology" has ensued from an actual experience of living. Africa lives with its "poverty and wars" that have caused famine, the destruction of property and social structures, and millions have been sent into displacement where there is no food or even clean water.

Matthew records examples in which Jesus participated in a feeding programme. In the wilderness, Satan tempted the hungry Jesus with food (Mt 4:2-3). In the controversial story of the hungry disciples (Mt 12:1-9), Jesus allowed them to pick corn on the Sabbath. Jesus disagreed with his disciples, who were reluctant to engage in this feeding programme without adequate food supplies (Mt 14:13-21; 15:29-39). Jesus pleaded with those who had to share with the people who were hungry and thirsty (Mt 10:42; 25:35-46). Jesus encouraged the people to trust in God, who took care of their basic needs such as feeding, clothing and shelter (Mt 6:25-34). Matthew's argument is that that "divine supplies" challenged the Roman empire and the Israelite patrons who were its collaborators on their failure to attend to the needy. Thus, blessed are those who desire to help those in need, because they are seen as "representatives of the Son of Man" (Van Tilborg 1986:29) on the judgment day.

There is a "small" debate among Matthean scholars concerning the fourth Beatitude that needs to be cleared up here. According to Van Tilborg (1986:28-31) and Sabourin (1982:347), ${ }^{11}$ this Beatitude concerns those who desire to do justice and righteousness, whereas Dupont (1969b:39-51) and Carter (2000:133-134) think that it actually concerns those whose justice and righteousness is denied or baffled. Jesus' audience includes all these categories, and the message needs to be applied to everyone in his or her own capacity. According to Luz ([1989] 1990:238), in Israelite and even Hellenistic traditions references to hunger and thirst mean "to long for and to make an effort for". It is against this background that one should understand

\footnotetext{
${ }^{11}$ Sabourin says that to hunger and thirst for righteousness "is a source of Beatitude, not a social condition of misery as such". But he overlooks the fact that both body and soul need equal salvation. Luz ([1989] 1990:237-238) also sides with those who think that the concept refers to human behaviour.
} 
the Matthean Jesus' demand that the degree of justice and righteousness should be greater than that of the Pharisees (Mt 5:20).

One can therefore expect that a statement such as "for they will be filled" (Mt 5:6) refers to the memories of those days when Israel had experienced God's presence and fullness. Even in the wilderness God fed (Ex 16:1-35), gave water (Ex 15:22-27; 17:6-8) and shelter ( $\mathrm{Nm} 2$ ) to wandering refugees while they were in a repatriation process. God had commanded Israelites to feed the hungry people, especially the homeless among them: the orphans, widows and aliens. During the harvest, the Israelites were instructed not to harvest the corners of their fields and to leave sheaves behind (Lv 19:910; Dt 24:19-22), so that the poor could get something to feed on. Naomi and Ruth were examples (Ruth 2) of such gleaners and Psalm 23 summarizes this notion.

These biblical reports remind readers of African socialism in the decolonization period (see Nkrumah [1964] 1970:77-78; Kaunda 1967; Nyerere 1968) and of the concept of ubuntu or ujamaa (communalism) which goes beyond one's own family circle to include all humanity around the village. In Africa tradition, leaders and elders felt that it was their duty to do justice and righteousness and to show mercy by alleviating human suffering in every way possible. The Matthean Jesus constantly reminds us about this life of the brotherhood/sisterhood of all humanity - the purpose of which is to find the essence of life in loving God and your neighbour (Mt 22:37-40) as the foundation of what the law and the prophets demand. However, if the (Lucan) question (Lk 10:26) about the neighbour is put forward to the Matthean community, the story of the "Canaanite mother" could provide an answer.

\section{THE CANAANITE MOTHER'S IDENTITY CRISIS REVISITED}

\subsection{Introduction}

The story of the Canaanite mother ${ }^{12}$ (Mt 15:21-28) occupies a central position in postcolonial criticism, since many scholars think that this story portrays

\footnotetext{
${ }^{12}$ Some years back, Rukundwa was invited to preach to a local Anglican congregation in a suburb of Bujumbura, Burundi. His message focused on the Canaanite woman (Mt 15:21-28). His Bible references were Swahili, French and English, and he did not pay attention to the Kirundi translation. But as he started his sermon, he asked one mother to do the Scripture reading for him. As she read through the first verses she used the term umugore which simply and generally means a woman or a wife. At the last verse, instead of using umugore, the Kirundi version uses "nyina wanje" which literally means "mother of mine" or simply a mother. This reading changed his understanding of the story, especially in terms of how Jesus was completely revolutionalized in his understanding of the Other. Therefore in the rest of this study, the term "mother" is implied.
} 


\section{Revisiting justice in the first four beatitudes in Matthew}

cultural, ethnic/tribal, economic, political and gender discrimination (cf Wainwright 1994:650-656; Donaldson 1996:1-12; Guardiola-Saenz 1997:6980; Levine 2001:22-41).

Hare's (1993:176-179) interpretation of the story of the Canaanite mother is well argued. He presents three possible theses of reading the anecdote: (i) The story is to be read as "inauthentic" because it was accredited to Jesus by Judean Christians who were opposed to the Gentile mission. (ii) The story is to be treated as "authentic", but "Jesus' behaviour is not [as] harsh as modern readers think". The story is then used to say that "charity begins at home", as a way of testing her faith: "... if she passes the test, he will accede to her request." (iii) The narrative is to be accepted the way it stands in all its "harshness". It presents Jesus as a Judean man of his time, "chauvinistic toward women and non-Jews". According to Hare, the Matthean Jesus is a tribal messiah whose mission is primarily limited within cultural boundaries, but whose mission could eventually change, depending on the receptivity or rejection of Israel.

A difficulty that arises from such "discriminative" reading is the failure to dissociate the christology of Jesus, whose healing mission is to do justice and righteousness in a borderless world, from a cultural ghetto. It may be argued that the socio-political, economic and religious context that emerges from Matthew's narration, particularly seen in the light of Roman colonization, influenced the Gospel's redaction. Matthew's "cultural conservation" can be seen as a reactionary measure against Roman imperialism (see Carter 2001), which undoubtedly created tensions between neighbours, including the inhabitants of Tyre and Sidon.

Another argument is that Matthew has been influenced by the cultural and traditional conflict that existed between the Israelite and Canaanite communities (see Guardiola-Saenz 1997) since the conquest history (cf Gn 12:4-6; Ex 3:7-10; Jos 13-22). To depend only on this argument is to overlook the long and good diplomatic relations between Israel and Tyre and Sidon during the Davidic reign (1 Ki 5). Tyre and Sidon also had played a very important role in commercial relations with Judea (Freyne 1980:114-121). It must also be remembered that during the Judean anti-colonial struggle from 66 to $70 \mathrm{CE}$, Sidonians ${ }^{13}$ protected the Judean population when an antiJudean campaign swept the whole region and Judeans were massacred (Barbour 1988:132).

The argument is that the Matthean Jesus confronted Roman imperialism and Israelite cultural and religious structures (Wainwright 1998:41-45) that hinder justice and righteousness from taking its course.

\footnotetext{
${ }^{13}$ However, according to Josephus, Tyre killed a great number of Judeans during this time of war (Barbour 1988:132).
} 
According to the Matthean Jesus, justice and righteousness is the essence of the whole existence of the law and the words of the prophets - which in a simple definition represent "the will of God". Using a psychoanalytic reading Dolto (1980:16-19; cf Mukendi 1997:56-57) suggests that both Jesus and the Canaanites (mother and daughter) are liberated from cultural and religious boundaries, from demons and cultural prejudices. Healing (see Crossan 1998:293-304; cf Dube 1996:123-127) is part of God's mission and should be seen as a means of resistance against social, political, religious and economic exploitation that rendered people unhealthy and miserable.

The Markan and Lucan reference to the healing of a man possessed by a demon is an interesting example. Roman oppression is implicitly referred to when the demons identify themselves as legions (Mk 5:9; Lk 8:30). Theissen ([1977] 1978:101-102) speaks of "transference" in his "psychoanalytic" approach to this episode. According to him, the resistance against the Romans can be seen in the exorcism, since the demons that live in the herd of swine "behave like [an] occupying power". This tells us how strongly the Judeans were opposed to foreign occupation, and this also applies to many oppressed people in other regions, including Tyre and Sidon. The same spirit of resistance against colonialism was felt across tricontinental countries in the face of European colonizers (see Young 2001).

On the other hand, those who have adopted a postcolonial theory to interpret the story of the Canaanite mother can also go the other extreme of "deconstructive theology" (see Wainwright 1998:91). This happens in the case of Guardiola-Saenz (1997:69-80), who argues from a "radical" feminist perspective. Guardiola-Saenz (1997:70) sees the Canaanite mother as a victim of her writer and her reader who "mistreated and incarcerated [her] in the oppressive boundaries of the text ... for their own benefit, maintaining the status quo". Wainwright (1998:91-92) also suggests that the structure and legitimacy of Jesus' healing power is highly "genderized" and "oppressive of women and others designated as outsiders". The power of healing and doing justice that is attributed to Jesus in this story "veil the violence that can be inherent in such power" (Wainwright 1998:91-92). Wainwright believes that these biases "may well have been - and hence can continue to be deconstructed". In a more rigid interpretation, Guardiola-Saenz (1997:76-77), says that the recognition of Jesus as the son of David by the Canaanite mother is not "a statement of faith" on her lips but it is an asseveration of protest and a demand of her rights from the "invader" and "oppressor". Such reading diminishes constructive interaction between the two main characters in the story. To avoid such temptation, one needs to rebuild a theological point of hope around Jesus' divine mission, which is essentially universal. 


\section{Revisiting justice in the first four beatitudes in Matthew}

\subsection{Social and political boundaries}

The encounter between Jesus and the Canaanite mother in Matthew (see, among others, Anderson 1983:14-16; Wainwright 1994:635-677; 1995:132153; 1998:84-92; 2001:126-137; Donaldson 1996:10-14; Dube 1996:111-129; Guardiola-Saenz 1997:67-81; Humphries-Brooks 2001:142-145; Jackson 2002; 2003:779-792), is one of the most interesting experiences in putting the Israelite law to the test: "... do not deprive justice to aliens among you" (Ex 22:21). Moreover, the context of the Canaanite mother fits the contemporary issues of discrimination based on race, region, tribe, ethnicity, class and gender. As Garland (1993:164) says, this story heightens modern sensitivities. Jesus' treatment of this Canaanite mother poses hermeneutical difficulties. Why did Jesus treat the desperate and poor mother in such a humiliating manner? Why did he create a polemic around his own teaching of loving God and one's neighbour (Mt 22:37-40)?

Once President Fidel Castro (in Young 2001:215) said that "colonies do not speak" and "are not known until they have an opportunity to express themselves." The silenced voice (see Wainwright 2001:127-128) of the Canaanite mother is a real example of what goes on in a world filled with inequalities. Like many colonized and marginal voices, the space to speak from is never peacefully negotiated, it is rather (re)claimed by means of resistance ${ }^{14}$ and insistence. In the story of the haemorrhaging woman (Mt 8:20-22), the unclean woman forcefully negotiated her healing by breaking cultural and religious barriers, which under normal circumstances subjected her to a life of isolation from the rest of the public (see Anderson 1983:11-12; Garland 1993:107; Carter 2000:320-321; Levine 1996:379-397; 2001:71). Also the Lucan reference to the widow and the bad judge (Lk 18:1-5) shows how another marginal person was silenced by the existing social and political structures. Yet, she forced her way through to get justice which was otherwise denied to her. Here too, Jesus was confronted with cultural and religious barriers that asked for liberation.

Moreover, in the case of the Canaanite woman, her status was not made known (Levine 2001:26). Nothing is known about her relatives, neighbours nor friends - in contrast to the paralytic man (Mt 9:1-8) who was carried by "some men", probably his relatives or neighbours. In this periscope, only she (herself) and her demonic possessed daughter are introduced. Moreover, we do not know whether she was married, a widow or a single mother. None of these questions is explicitly answered. She came alone pleading for help. However, according to Wainwright (1994:651), the matter is

\footnotetext{
${ }^{14}$ Resistance does not necessarily imply violence. It can also happen through non-violent procedures.
} 
more serious. She says that the identity of the mother is "a disability that made her unclean." The mother is ethnically categorized as the Canaanite, a term that makes her ethnically and religiously disqualifies her as a candidate for justice and righteousness in a Judean context. Hence, she was undoubtedly marginalized because of both her gender and her race (Dewey 1994:484; Wainwright 1994:651), and she was economically excluded because of her class.

The geographical location of the meeting between Jesus and the Canaanite mother is also not made clear. We can speculate that it was inbetween region, the area around the frontiers of Judea and the region of Tyre and Sidon (Mt 15:21). Matthew remains ambiguous, for he does not let Jesus leave the region of Galilee. By contrast, the Markan version tells us that Jesus crossed the borders (Mk 7:24). The use of the "Canaanite" identity is a Matthean version, while for Mark it is a "Syrophoenician" (i e, Greek) identity. During the first century, the Canaanite community as a people or a tribe were no longer existed but the term was used to denote a disgraceful people (see Dermience 1982:29; Selvidge 1987:79; Jackson 2002:60-100). However, it would be regarded as ungrateful towards the Canaanite women (see Humphries-Brooks 2001:138-156) if Judeans forgot or underestimated the political role that Rahab (Js 2) played by hiding Joshua's spies at Jericho and along with mother Tamar (Gn 38) by keeping alive the lineage (Mt 1:3,5) of Jesus whom the Canaanite mother is an aunt or a maternal cousin. ${ }^{15}$

According to Gottwald (1979:556-558), the alliance between the Israelites and the Canaanite woman at Jericho needs to be re-examined. In ancient cities prostitutes formed one of the several groups of occupational outcasts whose services were desired, but because of taboos, they were stigmatised and "worked under decided disabilities". For Rahab, this reality was enough reason for resentment against the ruling class in Jericho. She might have hoped that by siding with rebels, she could improve her economic situation and social status. It should also be understood that economic pressure might be a reality that pushed Rahab into harlotry to earn a living. In any case, her dealings with spies was important for Israel.

By contrast, Josephus (JW 2.478; Con Ap 1.70, cited in Carter 2000:321-322) shows that people from Tyre were enemies to the Judeans. Ethnic and religious clashes between them often occurred in the 60s CE. There were also various economic and political interests which united and divided them from time to time. The social and political relationship between

\footnotetext{
${ }^{15}$ From an African point of view, kinship counts and keeps ties within close and extended families.
} 


\section{Revisiting justice in the first four beatitudes in Matthew}

Galilee and Tyre-Sidon was decidedly lukewarm, based on the interests of the moment.

The Canaanite mother was caught in the middle of these lukewarm political and diplomatic relations. In most cases innocent people who live in border regions frequently fall victims to such inconsistent diplomatic ties ${ }^{16}$ (see Freyne 1980:118-121). Whatever the case, the mother might have learned about Jesus' charismatic leadership, which announced the advent of a just and healing kingdom (Mt 4:23-25;14:14;19:2; $21: 14$ ) that was different from the Roman (foreign) occupying force in the region. In those days, when the Romans regime oppressed the Mediterranean world (see Klausner [1925]1964:135-173), the desire for independence grew high not only among Judeans, but also among other people in the region, although the Judeans were more outspoken than most of other groups.

Therefore the news about Jesus, the "son of David" (Mt 15:22), which the Canaanite mother invoked, carried a political connotation. She probably remembered the old diplomatic ties between the kings David and Hiram (1 Kings 5:1-12). The mother presented Jesus as a regional saviour, in contrast to the "Judean messiah" concept that was introduced earlier in the Gospel (Mt $1: 23)$. The Canaanite mother joins the Magi to de-ethicise the newborn king (Mt 2:1-2), a saviour to whom aliens and outcasts could also have access to worship. In turn he would proclaim justice and righteousness to all humanity, regardless of the religious, racial and socio-economic status of the needy. However, the conversation between the mother and the "Judean delegation" gives a hint of an antagonistic relationship between the two regions. Yet, the mother was well informed about the person she was dealing with.

From psychoanalytic perspective, the mother made a very simple and polite prayer: "Lord, Son of David, have mercy on me" (Mt 15:22). The Canaanite mother seemed to be familiar with a known Judean liturgy. The way in which she engaged Jesus in dialogue, is certainly a prayerful manner with a particular wording, suggesting as one who has been in contact with Jesus' milieu (Mt 15:22, 23, 27). These are the same words that were generally used and found among the "lost sheep" - the people on the fringes of Israel (cf Mt 8:25; 9:27-28; 14:30; 17:15; 20:30-31; Mk 10:47) who did longed for justice and righteousness.

The attitude of Jesus' disciples (Mt 15:23) (see Humphries-Brooks 2001:142-143) is quite disturbing, especially given the physical and

\footnotetext{
${ }^{16}$ The experience of the Democratic Republic of Congo-Rwanda diplomatic relations is an example. When there is not a political problem between the two countries, people live in peace, particularly those in the border regions. But when politics change, they become victims. Other examples are the Kashmir border between India and Pakistan, or the borders of Poland and Germany during the Second World War.
} 
psychological stress, depression, and trauma that the mother and her daughter have experienced. The hostile attitudes of the disciples, the Pharisees and the crowds towards Jesus' compassion and intention to render justice and righteousness to the needy, are repeatedly mentioned in the various narratives (Mt 9:34; 12:1-14; 14:15-17; 15:33; 20:29-31; cf Mk 6:35$36 ; 8: 3-4 ; 10: 46-48 ;$ Lk 13:10-17; 18:15, 35-39). However, they were still to learn that Jesus' way was the way to fulfil the law and the prophets (Mt 5:17; $7: 12 ; 22: 40)$.

Because of the persistence of the mother (Mt 15:25), Jesus gave an even harsher response (Mt 15:26) than expected. Jackson (2002:54-58) emphasizes the use of the dog metaphor in biblical and rabbinic literature. The term "dog" was used as a metaphor to refer to the abuse of persons of the lower classes, according to Israelite social standards. The Lucan story of the rich man and Lazarus (Lk 16:19-31) is therefore significant in this regard. According to Van Aarde (1999:107), leftover food was not fit for use according to the purity regulations of the Temple. Yet this is what the dehumanised people long for to satisfy their hunger. In the parable, Lazarus shares scraps with dogs that turn out to be his sole companions. The dogs in this story, "nursed" Lazarus' sores as a way of showing "sympathy" to a desperate human being ${ }^{17}$ more than the rich man could do.

Even at this that stage of the story, the Canaanite mother still persists because her need had still not been attended to. The polite answer from the patiently waiting mother became a slap in the face of unbelieving Israel, compared to Tyre and Sidon (Mt 11:20-24; Lk 10:10-14), as well of the little faith demonstrated by Peter (Mt 14:31), and Jesus' other disciples (Mt 16:8$10 ; 17: 17)$. The knowledge of the mother about the master and the dog that eat from the same food (Mt 15:27), is important. As Levine (2001:40) puts it, the mother "provides a major means by which social hierarchies can, finally be broken down." In Israelite tradition, the dog does not only refer to Gentiles but also to the maimed, crippled, lame and undeserving sheep of the house of Israel (cf 2 Sm 9:8).

Nevertheless, the mother keeps her plea for justice and righteousness unchanged until Jesus overcomes the cultural, religious barriers and political prejudices and does the will of God. The Canaanite mother's reclamation of

\footnotetext{
${ }^{17}$ In May 2005 in Nairobi, Kenya, a dog was named mkombozi (saviour) after "showing mercy" to and saving a baby girl who was abandoned by her mother in a forest after delivery. The dog carried the plastic bag that contained the baby from the forest to a nearby settlement, and the owner of the dog took the baby to the hospital. It is said that the dog had puppies and had gone to look for food. Instead of continuing its search for food, the dog became "compassionate" and engaged in "humanitarian service" to save a life! It is as if the dog was surprised that animals like it can be more caring and understanding in doing "justice" than humans sometimes do!
} 


\section{Revisiting justice in the first four beatitudes in Matthew}

the wholeness of her daughter demonstrates not only her resistance against injustice done to women and foreigners, but also the risk of a misappropriation of God's healing power (see Levine 2001:26). The mother's plea liberated Jesus from a "Judean cultural ghetto" and helped him to discover a desire to help and support others. According to such a psychoanalytic reading (cf Dolto 1980:16-17; Mukendi 1997:56), Jesus was urged to behave like a Saviour, a Messiah beyond cultural and religious barriers. The mother introduces a very disturbing factor for the Matthean Jesus, namely the realisation that the community was going through a social mutation - that it eventually had to become hybrid (see Bhabha 1994:112-116; Young 1995:22-26; 2001:265274) - into a more accommodating community, a community of brotherhood and sisterhood.

Consequently, Jesus learned through these circumstances that he was to take care of all, regardless of their social-political and geographical provenance. Dolto (1980:18-19; cf Mukendi 1997:57) argues that Jesus then began to understand his mission differently and discovered the will of his Father to extend beyond his own cultural frontiers. The Matthean Jesus was, in other words, at school in terms of the discovery of God's will in a sense totally different from his Judean background. It was a woman (i e, his mother) who introduced Jesus to a public reality (Jn 2:1-11); and it was, the Canaanite mother who introduced him to the universal reality of God's healing mission beyond the boundaries of his own culture.

Jesus was surprised and touched by the mother's faith, by her persistence (Mt 15:28b). Did the mother want anything more? Were they both embarrassed by this type of species of diplomatic incident in their dialogue? Of course, the text does not go further than to narrate a healing act. But it is certain that the healing of the daughter turned the mood of mourning into one of joy, and a desire for justice and righteousness into satisfaction. Her poverty and uncleanness were turned into fullness and accommodation in the reign of God's kingdom of justice and righteousness.

Because he was a male Judean, Jesus' mission was shaped and delimited by Judean cultural and religious beliefs. In this case, he was instructed by his cultural milieu to believe that a Canaanite was not "one of them" (Jackson 2003:781). Yet, being a divine messenger whose task was to proclaim justice and righteousness to the afflicted (Lk 4:18-19), the illuminative thought of doing God's will - justice and righteousness (Mt 5:17; cf Ex 18:15; Jn 4: 34) - prevails. Therefore, ethnicity does not come first when justice and righteousness is to be administered, because of human needs that are to be given priority. The kingdom of God in the light of a universal 
brotherhood and sisterhood is a hybrid fabric in which all nations, tribes, races and, both genders find an equal and mutual existence.

\section{SUMMARY}

Becoming a chosen of God is not just a privilege, instead, it implies rather a responsibility to do justice and righteousness; to carry on a decolonising and healing mission; to take the good news to the poor and to the oppressed (cf Is 61:1-4). The well-being of the so-called underserved is the essence of the first four Beatitudes. In other words, justice and righteousness must be extended to those whose current colonial status and oppression by dictatorial structures deny them access to basic necessities. Jesus' teaching is a revolutionary teaching that challenges existing power structures that dehumanise the Other.

From an Israelite traditional viewpoint, the Canaanite mother had a clear view of her rights (although these are not explicitly stated in the pericope) and that she kept on insisting that strangers were not to be deprived of their justice (Dt 24:17). For anyone to deprive others of the basic necessities for a happy existence "constituted immoral conduct" (Knight 1989:81). According to Elaine Wainwright (in Van Aarde 2005:20), Jesus' restoration of the daughter to new life is "a manifestation of the liberating and inclusive nature of the basiliea". The healing of the daughter falls into the mission of empowering women, which restores back their strength, to face the challenges of life in an imbalanced and gendered society. However, the application of this message is relevant to many millions across the globe who are still oppressed and exploited by the powerful today.

Our continents are under siege by evil powers, in the form of imperialism, terrorism or dictatorship and civil wars. Unfortunately, the powerful remain the agents of evil. Because of the political and economic ambitions of the powerful in many countries, many inhabitants have been reduced to beggars, refugees, homeless and landless in their own land and beyond, with no adequate means of subsistence. Others have become constant mourners, orphans and widows, some are sexually abused, while their cry for justice and righteousness goes unheard. Therefore, God is to be constantly reminded of the establishment of his kingdom on earth so that God's people may be whole once again. At the same time, the church is to be reminded, through Jesus Christ, that the church ought to be the agent of God's justice and righteousness in this wretched and corrupt world.

\section{Works consulted}

Allison Jr, D J 1993. The new Moses: A Matthean typology. Minneapolis, MN: Fortress.

Anderson, J C 1983. Matthew: Gender and reading. Semeia 28, 3-27. 
Anderson, J C 1996. Matthew: Sermon and story, in Bauer, R D \& Powell, A M (eds), Treasures new and old: Contributions to Matthean studies, 233-250. Atlanta, GA: Scholars Press.

Barbour Publishing Inc 1988. Josephus, thrones of blood: a history of the times of Jesus $37 B C$ to $A D$. 70 ? Uhrichsville: Barbour Publishing Inc.

Bhabha, H K 1994. The location of culture. London: Routledge.

Bligh, J 1975. The Sermon on the Mount: A discussion on Mt 5-7. Slough: St Paul.

Boice, M J 1972. The Sermon on the Mount: An exposition. Grand Rapids, MI: Zondervan.

Cabral A 1980. Unity and struggle: Speeches and writings, tr by M Wolfers. London: Heinemann.

Carter, W 2000. Matthew and the margins: A socio-political and religious reading. Sheffield: Sheffield Academic Press.

Carter, W 2001. Matthew and empire: Initial explorations. Harrisburg, PA: Trinity Press International.

Crossan, D J 1998. The birth of Christianity: Discovering what happened in the years immediately after the execution of Jesus. San Francisco, CA: Harper San Francisco.

Dermience, A 1982. La péricope de la cananéenne (Mt 15:21-28): Rédaction et théologie. ETL 58, 25-49.

Dewey, J 1994. The Gospel of Mark, in Fiorenza 1994:470-509.

Dolto, F 1980. L'évangile au risque de la psychanalyse, vol 2. Paris: Le Cerf.

Donaldson, L T 1985. Jesus on the mountain: A study in Matthean theology. Sheffield: TSOT Press.

Donaldson, E L 1996. Postcolonialism and biblical reading: An introduction. Semeia 75, 1-14.

Dube, W M 1996. Reading of Semoya: Batwana women's interpretations of Matthew 15:21-28. Semeia 73, 111-129.

Duling, D C 1995. The Matthean brotherhood and marginal scribal leadership, in Esler, P F (ed), Modelling early Christianity: Socio-scientific studies in the New Testament in its context 159-181. London: Routledge.

Dupont, J 1969a. Les Béatitudes: Tome I. Le problème littéraire: Les deux versions du sermon sur la montagne et des béatitudes ( $2^{\text {nd }}$ ed). Paris: J Gabalda et Cte Editeurs.

Dupont, J 1969b. Les Béatitudes: Tome II, La bonne nouvelle. Paris: J Gabalda et Cte Editeurs.

Dupont, J 1973. Les Béatitudes: Tome III, Les Evangélistes. Paris: J Gabalda et Cte Editeurs.

Freyne, S 1980. Galilee from Alexander the Great to Hadrian 323 BCE to 135 CE. Wilmington: Michael Glazier.

Garland, D E 1993. Reading Matthew: A literary and theological commentary on the first Gospel. London: SPCK.

Gottwald, N K 1979. The tribes of Yahweh: A sociology of the religion of liberated Israel, 1250-1050 BCE. London: SCM.

Guardiola-Saenz, A L 1997. Borderless women and borderless texts: A cultural reading of Matthew 15:21-28. Semeia 78, 67-81. 
Guha, R 1982. Subaltern Studies: Writings on South Asian history and society. New Delhi: Oxford University Press.

Hagner, D A 1993. Matthew 1-13, vol 33A. Dallas, TX: Word Books Publisher. (Word Biblical commentary.)

Hare, D R A 1993. Matthew. Louisville, KY: Westminster John Knox.

Horsley, R A 1993. Jesus and the spiral of violence: Popular Jewish resistance in Roman Palestine. Minneapolis, MN: Fortress Press.

Humphries-Brooks, S 2001. The Canaanite women in Matthew, in Levine, A-J \& Blickenstaff, M (eds), A feminist companion to Matthew 138-156. Sheffield Academic Press.

Jackson, G S 2002. "Have mercy on me": The story of the Canaanite woman in Matthew 15:21-28. Sheffield: Sheffield Academic Press.

Jackson, G S 2003. Enemies of Israel: Ruth and the Canaanite Woman. HTS 59, 779-792.

Kaunda, K D 1967. Humanism in Zambia and a guide to its implementation. Lusaka: Zambia Information Services.

Kee, C H 1997. To every nation under heaven: The Acts of the Apostles. Harrisburg, PA: Trinity Press.

King, M L [1968] 1992. I have a dream: Writings and speeches that changed the world, ed by J M Washington. San Francisco: Harper San Francisco.

Klausner, J [1925] 1964. Jesus of Nazareth: His life, times and teaching, tr by $\mathrm{H}$ Danby. Boston: Beacon.

Knight, A D 1989. The ethics of human life in the Hebrew Bible?, in Knight \& Paris (ed), Justice and the holy: Essays in honor of Walter Harrelson, 65-88. Atlanta, GA: Scholars Press.

Levine, A-J 1996. Discharging responsibility: Matthean Jesus, biblical law, and haemorrhaging woman, in Bauer \& Powell 1996:379-397

Levine, A-J 2001. Matthew's advice to a divided readership, in Aune, E D (ed), The Gospel of Matthew in current study 22-40. Grand Rapids, MI: W B Eerdmans.

Lohfink, N 1997. The appeasement of the Messiah: Thoughts on Ps 37 and the third Beatitude. Theology Digest 44(3), 234-241.

Luz, U [1989] 1990. Matthew 1-7: A commentary, tr by W C Linss. Edinburgh: T\&T Clark.

Luz, U [1993] 1995. New Testament theology: The theology of the Gospel of Matthew tr by R B Jin. Cambridge: University Press.

Malina B J and Rohrbaugh R L 1992. Social-science commentary on the synoptic Gospels. Minneapolis, MN: Fortress.

Mukendi, F M 1997. Herméneutique athée et exégèses modernes. A propos d'un thème capital de la foi chrétienne: le Fils de l'homme. Kijabe: Kijabe Printing Press.

Nkrumah, K [1964] 1970. Consciencism: Philosophy and ideology for decolonization, rev ed. New York: Monthly Review Press.

Nyerere, J K 1968. Ujamaa: Essays on socialism. Dar es Salaam: Oxford University Press.

Oakman D E 1986. Jesus and the economic questions of his day. Lewiston: The Edwin Mellen Press. 


\section{Revisiting justice in the first four beatitudes in Matthew}

Oakman D E 1999. The Lord 's Prayer in social perspective, in D Chilton \& C A Evans (eds), Authenticating the words of Jesus, 137-186. Leiden: Brill.

Oduyoye, A M 1998. African women's hermeneutics, in Maimela \& König (eds). Initiation into theology: The rich variety of theology and hermeneutics, 359371. Pretoria: J L Van Schaik

Phan, C P 1997. Experience and theology: An Asian liberation perspective. Theology Digest 44(3), 225-230.

Pixley, V G \& Boff, C 1995. A Latin American perspective: The option for the poor in the Old Testament, in Sugirtharajah 1995:215-227.

Powell, A M 1996. Matthew's Beatitudes: Reversals and rewards of the kingdom. CBQ 1996, 58(2), 460-479.

Richardson, J E M 2000. Hammurabi's laws, text, translation and glossary. Sheffield: Sheffield Academic Press.

Sabourin L S J 1982. The Gospel according to St Matthew: General introduction \& commentary 1:1-7:2 7, vol 1. Bombay: St Paul Publication.

Segal, A F 1991. Matthew's Jewish voice, in Balch, D L (ed) 1991. Social history of the Matthean community: Cross-disciplinary approaches, 3-37. Minneapolis: Fortress Press.

Segovia, F F (ed) 2000. Interpreting beyond borders. Sheffield: Sheffield Academic Press.

Selvidge, M J 1987. Daughters of Jerusalem. Ontario: Herald Press.

Spivak, G C 1988. In other worlds: Essays in cultural politics. London: Routledge.

Stark, R 1991. Antioch as the social situation for Matthew's Gospel, in Balch 1991:189-205.

Sugirtharajah, S R 1999. A brief memorandum on postcolonialism and Biblical studies. JSNT 73, 3-5.

Theissen G [1977] 1978. Sociology of early Palestinian Christianity, tr by J Bowden. Philadelphia, PA: Fortress.

Theological Dictionary of the New Testament 1968. s v "peino".

Ukpong, J 1992. The Immanuel Christology of Matthew 25:31-46 in African context, in Pobee 1992:55-83.

Van Aarde, A G 1999. Fatherless in the first-century Mediterranean culture: The historical Jesus seen from the perspective of cross-cultural anthropology and cultural psychology. HTS 55, 97-119.

Van Aarde, A G 2001. Fatherless in Galilee: Jesus as a child of God. Harrisburg: Trinity Press International.

Van Aarde, A G 2005. IHSOUS - the Davidic Messiah, as political savior in Matthew's history, in Van der Watt, J G (ed), Salvation in the New Testament: Perspectives on soteriology, 7-31. Leiden: Brill. (Supplements to Novum Testamentum.)

Van Tilborg, S 1986. The Sermon on the Mount as an ideological intervention. Assen: Van Gorcum.

Wainwright, M E 1994. The Gospel of Matthew, in Fiorenza, S E, (ed), Searching the Scriptures. A feminist commentary, 635-677. London: SCM.

Wainwright, M E 1995. A voice from the margin: Reading Matthew 15:21-28, in An Australian feminist key, in Segovia \& Tolbert 1995:132-153.

Wainwright, M E 1998. Shall we look for another?: A feminist reading of the Matthean Jesus. New York: Orbis books. 
Wainwright, M E 2001. Not without my daughter: Gender and demon possession in Matthew 15:21-28, in Levine \& Blickenstaff 2001:126-137.

Weinfeld, M 1995. Social justice in ancient Israel and in the ancient Near East. Jerusalem: The Hebrew University.

Witherington, B 1998. The Acts of the Apostles: A socio-rhetorical commentary. Grand Rapids, MI: W B Eerdmans.

Young, R J C 1995. Colonial desire: Hybridity in theory, culture and race. London: Routledge.

Young, R J C 2001. Postcolonialism: An historical introduction. London: Blackwell. 